\title{
Quantification of beta-cell function during IVGTT in Type II and non-diabetic subjects: assessment of insulin secretion by mathematical methods
}

\author{
L. L.Kjems ${ }^{1}$, A. Vølund ${ }^{2}$, S. Madsbad ${ }^{1}$ \\ ${ }^{1}$ Department of Endocrinology, Hvidovre University Hospital, Hvidovre, Denmark \\ ${ }^{2}$ Novo Nordisk, Bagsvaerd, Denmark
}

\section{Abstract}

Aims/hypothesis. We compared four methods to assess their accuracy in measuring insulin secretion during an intravenous glucose tolerance test in patients with Type II (non-insulin-dependent) diabetes mellitus and with varying beta-cell function and matched control subjects.

Methods. Eight control subjects and eight Type II diabetic patients underwent an intravenous glucose tolerance test with tolbutamide and an intravenous bolus injection of C-peptide to assess C-peptide kinetics. Insulin secretion rates were determined by the Eaton deconvolution (reference method), the Insulin SECretion method (ISEC) based on population kinetic parameters as well as one-compartment and two-compartment versions of the combined model of insulin and C-peptide kinetics. To allow a comparison of the accuracy of the four methods, fasting rates and amounts of insulin secreted during the first phase (0-10 $\mathrm{min})$ and the second phase (10-180 $\mathrm{min})$ were calculated.

Results. All secretion responses from the ISEC method were strongly correlated to those obtained by the
Eaton deconvolution method $(r=0.83-0.92)$. The one-compartment combined model, however, showed a high correlation to the reference method only for the first-phase insulin response $(r=0.78)$. The two-compartment combined model failed to provide reliable estimates of insulin secretion in three of the control subjects and in two patients with Type II diabetes. The four methods were accurate with respect to mean basal and first-phase secretion response. The one-compartment and two-compartment combined models were less accurate in measuring the second-phase response.

Conclusion/interpretation. The ISEC method can be applied to normal, obese or Type II diabetic patients. In patients with deviating kinetics of C-peptide the Eaton deconvolution method is the method of choice while the one-compartment combined model is suitable for measuring only the first-phase insulin secretion. [Diabetologia (2001) 44: 1339-1348]

Keywords Beta-cell function, Type II diabetes, intravenous glucose tolerance test, insulin secretion, mathematical models.
Type II (non-insulin-dependent) diabetes mellitus is characterised by a progressive functional beta-cell defect [1-5] and a precise measurement of insulin secretion is therefore important. However, an accurate

Received: 4 January 2001 and in revised form: 8 June 2001

Corresponding author: Dr. S. Madsbad, Department of Endocrinology, Kettegaard Alle, 2650, Hvidovre, Copenhagen, Denmark, e-mail: sten.madsbad@hh.hosp.dk

Abbreviations: ISEC, Insulin SECretion method. evaluation of insulin secretion involves methodological difficulties [6]. Direct measurement of plasma insulin and C-peptide concentration responses or both to beta-cell stimuli is still the most commonly used method. The kinetics of insulin and C-peptide are influenced by various factors and consequently peripheral insulin or C-peptide concentrations do not always reflect the actual endogenous insulin secretion [6-14]. To overcome these problems, several mathematical methods have been developed to calculate beta-cell secretion from peripheral insulin or C-pep- 
Table 1. Summary of clinical characteristics of the study subjects (means with SEM)

\begin{tabular}{|c|c|c|c|c|c|}
\hline & Age (years) & Weight (kg) & Height $(\mathrm{cm})$ & $\mathrm{BMI}\left(\mathrm{kg} / \mathrm{m}^{2}\right)$ & $\begin{array}{l}\text { Fasting BG } \\
(\mathrm{mmol} / \mathrm{l})\end{array}$ \\
\hline Control subjects: 4 females, 4 males & $52.9 \pm 4.0$ & $90.9 \pm 5.6$ & $173.4 \pm 4.4$ & $30.15 \pm 1.31$ & $5.5 \pm 0.1$ \\
\hline Type II diabetic patients: 4 females, 4 males & $47.9 \pm 3.4$ & $87.8 \pm 3.9$ & $169.6 \pm 2.5$ & $30.62 \pm 1.52$ & $10.0 \pm 1.3$ \\
\hline
\end{tabular}

tide concentrations [15-27]. These include the Eaton deconvolution method $[15,16]$, the Insulin SECretion method (ISEC) [17-19] and the combined model with one-compartment $[23,24]$ or two-compartments for C-peptide kinetics $[25,26]$ (see Methods). The deconvolution technique has been used in many physiological and pathological conditions $[5,7,10,15,16$, 28-30] and has been simplified by using populationbased kinetic parameters of C-peptide instead of individually determined parameters [17]. Investigators [17] determined population-based C-peptide kinetic parameters based on regression analysis of data from 250 normal, obese and Type II diabetic subjects and these were applied to the ISEC method $[18,19]$.

The combined model $[23,24]$ uses only insulin and C-peptide concentrations obtained during the day of experiment and is not restricted to a certain protocol or subjects from a specific population. This model has later been modified to encompass two-compartment C-peptide kinetics [25, 26]. We have recently assessed the accuracy of the original deconvolution method and the combined model during slow changes in insulin appearance rates, as seen during an oral glucose tolerance test [31]. However, limited information is available on the accuracy of these methods in estimating insulin secretion during fast dynamics, e.g. intravenous glucose tolerance test, in subjects with normal and impaired glucose tolerance. We aimed to assess these methods under the conditions of rapid dynamics of plasma insulin and C-peptide in relevant groups of human subjects with normal glucose tolerance and Type II diabetes mellitus.

We compared the accuracy of the four methods, using the deconvolution method $[15,16]$ as the reference method.

\section{Subjects and methods}

Subjects. Eight patients with Type II diabetes and eight control subjects, all Caucasian, were examined (subject characteristics are given in Table 1). The two groups were matched according to age, gender and BMI. The diabetic patients were only treated with diet and oral anti-diabetic agents. Their mean disease duration was 7 years (range 1-12 years) and glycated haemoglobin $\left(\mathrm{HbA}_{1 \mathrm{C}}\right)$ within the range of $5-12 \%$. All oral antidiabetic agents were withdrawn at least three days before the study. None had vascular, renal, eye or neurological complications and none had hepatic or endocrine diseases apart from diabetes mellitus. The control subjects had no family history of diabetes mellitus and none were taking any medication known to influence glucose metabolism. All studies were carried out in the Department of Endocrinology, Hvidovre University Hospital, Copenhagen, Denmark. Subjects gave their written informed consent and the protocols were approved by the local Committees of Ethics in Copenhagen and done in accordance with the Helsinki Declaration II.

Methods. Two experiments were done in random order on different days (at least 7 days apart). The subjects attended the ward in the morning after overnight fasting including no smoking. An intravenous sampling catheter (heparinised polyethylene catheter, Viggo, Vingmed, Denmark) was inserted into the dorsum of the hand and an infusion catheter was maintained in a heating blanket to ensure "arterialization" of the venous samples, and the cannula was kept open with $0.9 \%$ saline. Specially coated syringes and tubing lines (Braun, Germany) were used for all infusions of peptides to avoid adhesion of the peptides to the plastic material.

Protocol 1: Assessment of C-peptide kinetics. Each subject received a priming bolus of $500 \mu \mathrm{g}$ somatostatin (Durascan Medical Products, Odense, Denmark) intravenously, followed by a somatostatin infusion $(500 \mu \mathrm{g} / \mathrm{h})$ starting $90 \mathrm{~min}$ before injection of C-peptide and continuing throughout the experiment. Blood samples were taken at $-10,-5$ and 0 minutes. At 0 min, a bolus of $50 \mathrm{nmol}$ biosynthetic human C-peptide (Bachem Feinkemikalien, Bubendorf, Switzerland) was given intravenously over $30 \mathrm{~s}$ and blood samples were taken at 2, 3, 4, 5, 6, $7,8,9,10,11,12,14,17,20,25,30,35,40,45,50,60,70,80,90$, $100,120,140,160$ and $180 \mathrm{~min}$ to measure plasma C-peptide

Protocol 2: Intravenous glucose tolerance test (IVGTT). A standard frequently sampled IVGTT with tolbutamide was done. Baseline blood samples were taken at $-10,-5$ and 0 min. At $0 \mathrm{~min}, 0.3 \mathrm{~g} / \mathrm{kg} 50 \%$ D-glucose (SAD, Copenhagen, Denmark) was given intravenously over $1 \mathrm{~min}$ and blood samples were taken at $3,4,5,6,7,8,10,12,14,17$ and $19 \mathrm{~min}$. At $20 \mathrm{~min}$ a bolus of $300 \mathrm{mg}$ tolbutamide (Hoechst, Germany) dissolved in saline was given intravenously over $30 \mathrm{~s}$, and samples were taken at $22,23,24,25,27,30,35,40,45,50,60,70,80,90,100,120$, 140,160 and $180 \mathrm{~min}$ to measure plasma insulin, C-peptide and glucose.

Sample collection and analytical techniques. Blood samples for insulin and C-peptide were drawn in chilled tubes containing $500 \mathrm{KIU} / \mathrm{ml}$ aprotinin and heparine fluoride and placed on ice. All samples were centrifuged immediately at $4{ }^{\circ} \mathrm{C}, 3000$ rpm for $20 \mathrm{~min}$ and pipetted into three separate tubes; one for insulin measurement, one for C-peptide and one for additional measurements. The C-peptide samples were stored at $-80^{\circ} \mathrm{C}$ and the insulin samples were stored at $-20^{\circ} \mathrm{C}$ until assayed. Plasma insulin was assayed in duplicate by a highly sensitive two-site enzyme-linked immunosorbent assay [32]. The assay is based on two monoclonal antibodies (Novo Nordisk A/S) specific for intact human insulin. The intra-assay coefficient of variation was $4 \%$ and the detection limit $5 \mathrm{pmol} / 1$ (assay range 5-2000 pmol/l). Human C-peptide was measured in duplicate with a radioimmunoassay $[33,34]$. The intra-assay coef- 
ficient of variation was $4 \%$ and the detection limit of the assay $100 \mathrm{pmol} / \mathrm{l}$. Plasma glucose concentration was measured immediately using the glucose oxidase method on a Yellow Spring Glucose Analyser (Yellow Spring Instruments Co., Yellow Spring, Ohio, USA).

Mathematical models. The two-compartment model for C-peptide was applied [35]. The following biexponential model was fitted to the individual C-peptide concentrations measured according to protocol 1 :

$\mathrm{C}(\mathrm{t})=\alpha_{0}+\alpha_{1} \exp \left(-\beta_{1} \mathrm{t}\right)+\alpha_{2} \exp \left(-\beta_{2} \mathrm{t}\right)$

$\mathrm{C}(\mathrm{t})$ represents the concentration at time $\mathrm{t}$ of $\mathrm{C}$-peptide in the plasma after injection of the dose $\mathrm{D}$ at time 0 . The parameter $\alpha_{0}$ represents the possibly incomplete suppressed concentration of endogenous C-peptide. The parameters $\alpha_{1}, \beta_{1}, \alpha_{2}$ and $\beta_{2}$ were used to calculate the secretion rate during the IVGTT by means of deconvolution of the measured C-peptide concentrations. The kinetic parameters of the two-compartment model for C-peptide $\mathrm{k}_{01}$ (elimination from the plasma compartment), $\mathrm{k}_{21}, \mathrm{k}_{12}$ (transfer rates between compartments) and the apparent volume of the plasma compartment $V_{1}=\mathrm{D} /$ $\left(\alpha_{1}+\alpha_{2}\right)$ were calculated [16]. We also calculated the apparent volume of the second (extravascular) compartment $\mathrm{V}_{2}=\mathrm{V}_{1} \mathrm{k}_{21}$ I $\mathrm{k}_{12}$ and the clearance rate $\mathrm{Cl}=\mathrm{k}_{01} \mathrm{~V}_{1}$.

Deconvolution methods. The original deconvolution method [15] used a cubic spline function to smooth the measured Cpeptide concentration profile followed by calculation of the secretion rate from the equations for the two-compartment model:

$\mathrm{dC}_{1}(\mathrm{t}) / \mathrm{dt}=-\left(\mathrm{k}_{01}+\mathrm{k}_{12}\right) \mathrm{C}_{1}(\mathrm{t})+\mathrm{k}_{21} \mathrm{C}_{2}(\mathrm{t})+\mathrm{S}(\mathrm{t})$

$\mathrm{dC}_{2}(\mathrm{t}) / \mathrm{dt}=\mathrm{k}_{21} \mathrm{C}_{1}(\mathrm{t})-\mathrm{k}_{12} \mathrm{C}_{2}(\mathrm{t})$

$\mathrm{C}_{1}(\mathrm{t})$ and $\mathrm{C}_{2}(\mathrm{t})$ represent the amounts of C-peptide in the two compartments and $\mathrm{S}(\mathrm{t})$ is the secretion rate at time $\mathrm{t}$. We used a cubic spline function to describe the secretion rate, which can be estimated by fitting the convoluted spline function based on the estimated individual kinetic parameters to the measured C-peptide by a multiple linear regression analysis [23, 31]. The inherent tendency of deconvolution methods to show large fluctuations between sampling time intervals was avoided by choosing the knot points of the spline to be preceded and followed by three to four sampling times. The deconvolution method calculates the C-peptide secretion rate, which is equal to the insulin secretion rate if hepatic extraction of $\mathrm{C}$ peptide is zero and insulin and C-peptide are secreted at equimolar rates.

To avoid measuring each individual's C-peptide kinetics, investigators calculated population-based parameters adjusted for clinical status (normal, obese or Type II diabetes), age, gender, height and body weight by regression analysis of a large number of individual kinetic parameters [17]. We used a method adapted to computer use, denoted ISEC [18, 19]. This ISEC method uses the population-based C-peptide kinetics parameters and a regularisation method of deconvolution constrained to non-negative values. For both deconvolution methods and both combined models a basal (initial) steady state was assumed and confirmed by the constant concentrations of insulin and C-peptide before IVGTT.

Combined models. The combined models describe the kinetics of endogenous plasma insulin and C-peptide concentrations during a single experimental test as the result of a common equimolar pre-hepatic secretion rate [23-26]. The combined models also assume that the fraction of insulin extracted by the liver remains constant during the experiment corresponding to the assumption that insulin elimination kinetics do not change. Insulin and C-peptide appear in the systemic circulation at rates $\mathrm{F} \cdot \mathrm{R}(\mathrm{t})$ and $\mathrm{R}(\mathrm{t})$, respectively, and the fraction $(1-\mathrm{F})$ of newly, as well as previously, secreted insulin is taken up by the liver during each passage. Using the one-compartment models for insulin and C-peptide kinetics the equations for the combined model are [23]:

$\mathrm{dI}(\mathrm{t}) / \mathrm{dt}=-\mathrm{k}_{\mathrm{I}} \mathrm{I}(\mathrm{t})+\mathrm{f} \cdot \mathrm{r}(\mathrm{t})$

$\mathrm{dC}(\mathrm{t}) / \mathrm{dt}=-\mathrm{k}_{\mathrm{C}} \cdot \mathrm{C}(\mathrm{t})+\mathrm{r}(\mathrm{t})$

$\mathrm{I}(\mathrm{t})$ and $\mathrm{C}(\mathrm{t})$ are the concentrations of insulin and C-peptide at the time $t$ in arterial plasma. The $V_{I}$ and $V_{C}$ are the insulin and C-peptide distribution volumes, respectively, and $\mathrm{k}_{\mathrm{I}}$ and $\mathrm{k}_{\mathrm{C}}$ are the corresponding elimination rate constants of the peptides. The $\mathrm{r}(\mathrm{t})=\mathrm{R}(\mathrm{t}) / \mathrm{V}_{\mathrm{C}}$ is the secretion rate per unit distribution volume of $\mathrm{C}$-peptide and $\mathrm{f}=\mathrm{F} \cdot \mathrm{V}_{\mathrm{C}} / \mathrm{V}_{\mathrm{I}}$.

Of note, the pre-hepatic secretion rate $\mathrm{r}(\mathrm{t})$ appears in both the above equations, allowing the estimation of the individual parameters $\left(\mathrm{f}, \mathrm{k}_{\mathrm{I}}\right.$ and $\mathrm{k}_{\mathrm{C}}$ ) as well as $\mathrm{r}(\mathrm{t})$ from the concentrations of insulin and C-peptide as a function of time. A computer programme written in APL was designed to perform the calculations [23]. The programme uses a cubic spline function to represent $\mathrm{r}(\mathrm{t})$ with knot points chosen at suitable time points as described above. To convert secretion rates expressed in $\mathrm{pmol} / \mathrm{min}$ per unit distribution volume of C-peptide to $\mathrm{pmol} /$ min per $\mathrm{kg}$ body weight, a value of $0.125 \mathrm{l} / \mathrm{kg}$ was used for $\mathrm{V}_{\mathrm{C}}$ [23].

This model has been extended to encompass two-compartment C-peptide kinetics $[25,26]$. The insulin equation remained unchanged, but the $\mathrm{C}$-peptide equation was replaced by equations (2) and (3) where $\mathrm{r}(\mathrm{t})=\mathrm{S}(\mathrm{t}) / \mathrm{V}_{1}$ and $\mathrm{f}=\mathrm{F} \cdot \mathrm{V}_{1} / \mathrm{V}_{\mathrm{I}}$. Although only the insulin and $\mathrm{C}$-peptide concentrations in the vascular compartment $(\mathrm{I}(\mathrm{t})$ and $\mathrm{C}(\mathrm{t}))$ can be measured, the five parameters $\mathrm{f}, \mathrm{k}_{\mathrm{I}}, \mathrm{k}_{01}, \mathrm{k}_{21}, \mathrm{k}_{12}$ as well as $\mathrm{r}(\mathrm{t})$ can be identified by an ingenious method described [25]. $r(t)$ describes now the rate of $\mathrm{C}$-peptide appearance in the vascular compartment and to obtain the secretion rate per $\mathrm{kg}$ of body weight a conversion factor of $0.0602 \mathrm{l} / \mathrm{kg}$ was used [25]. The properties of the four methods are summarised in Table 2 .

Data analysis and statistical methods. For each subject, insulin secretion rates were calculated, firstly, by the deconvolution methods based on individual C-peptide kinetics and, secondly, the ISEC method based on the population parameters as well as the two versions of the combined model. The goodness of fit was evaluated by calculating the deviations between measured and fitted concentrations. The accuracy was evaluated by calculating the $95 \%$-confidence limits for the differences between the secretion rates obtained with the reference method and the other methods. The precision of the individual kinetic parameters for the reference method and the combined models was estimated by non-linear regression analysis. The method based on population kinetic parameters did not, however, provide error estimates for the individual parameters. For comparison between the methods, fasting rates and the amounts of insulin secreted during the first (0-10 min) and second phase (10-180 min) were calculated. A comparison of results from the control subjects and diabetic patients was made using the Mann-Whitney test or $t$ tests depending on whether the distribution assumptions were considered acceptable. Results obtained by two different methods in the same subjects were compared by Wilcoxon's test or the $t$ test for paired 
Table 2. Schematic description of the methods for assessing insulin secretion

\begin{tabular}{|c|c|c|c|c|}
\hline Method & $\begin{array}{l}\text { Reference method [15, } \\
16]\end{array}$ & $\begin{array}{l}\text { Deconvolution method } \\
\text { with population-based pa- } \\
\text { rameters for C-peptide } \\
{[17,18,19]}\end{array}$ & $\begin{array}{l}\text { Combined model, one- } \\
\text { compartment of insulin } \\
\text { and C-peptide [23] }\end{array}$ & $\begin{array}{l}\text { Combined model, one-com- } \\
\text { partment of insulin and two- } \\
\text { compartment for C-peptide } \\
{[25,26]}\end{array}$ \\
\hline Assumptions & $\begin{array}{l}\text { Equimolar secretion rates } \\
\text { of insulin and C-peptide, } \\
\text { negligible first pass up- } \\
\text { take of C-peptide prior to } \\
\text { blood sampling, two-com- } \\
\text { partment model for C- } \\
\text { peptide kinetics with eli- } \\
\text { mination from the plasma } \\
\text { compartment and ex- } \\
\text { change with a second } \\
\text { compartment }\end{array}$ & $\begin{array}{l}\text { Same as for reference me- } \\
\text { thod }\end{array}$ & $\begin{array}{l}\text { Same as for reference me- } \\
\text { thod except for one-com- } \\
\text { partment models for C- } \\
\text { peptide and insulin kinet- } \\
\text { ics }\end{array}$ & $\begin{array}{l}\text { Same as for reference me- } \\
\text { thod plus one-compartment } \\
\text { model for insulin kinetics }\end{array}$ \\
\hline Validation & $\begin{array}{l}\text { Dogs, normal and diabetic } \\
\text { subjects }[7,9,16,31]\end{array}$ & Normal subjects [19] & $\begin{array}{l}\text { Dogs and normal and dia- } \\
\text { betic subjects }[23,31]\end{array}$ & Dogs [26] \\
\hline Applicability & $\begin{array}{l}\text { All kinds of secretion stu- } \\
\text { dies, all types of subjects }\end{array}$ & $\begin{array}{l}\text { All kinds of secretion stu- } \\
\text { dies in normal, obese and } \\
\text { Type II diabetes only }\end{array}$ & $\begin{array}{l}\text { All kinds of studies and } \\
\text { subjects exhibiting varia- } \\
\text { tion in secretion }\end{array}$ & $\begin{array}{l}\text { All kinds of studies and sub- } \\
\text { jects exhibiting variation in } \\
\text { secretion }\end{array}$ \\
\hline $\begin{array}{l}\text { Resource re- } \\
\text { quirements }\end{array}$ & $\begin{array}{l}\text { Extra test with intrave- } \\
\text { nous bolus injection in } \\
\text { each subject to determine } \\
\text { kinetic parameters, me- } \\
\text { asurement of C-peptide } \\
\text { but not insulin }\end{array}$ & $\begin{array}{l}\text { Measurement of C-pepti- } \\
\text { de only }\end{array}$ & $\begin{array}{l}\text { Measurement of insulin } \\
\text { and C-peptide }\end{array}$ & $\begin{array}{l}\text { Measurement of insulin } \\
\text { and C-peptide }\end{array}$ \\
\hline
\end{tabular}

data. The correlations were assessed by the product-moment correlation or the Spearman rank correlation. Unless otherwise stated, results are reported as means \pm standard error of the means (SEM). A $p$ values of less than 0.05 was considered to be statistically significant.

\section{Results}

Individual C-peptide kinetics. The mean C-peptide decay curves for the diabetic patients and the control subjects were almost identical (Fig.1). The mean Cpeptide kinetic parameters were obtained by fitting equation (1) to the individual data followed by conversion of the estimates of $\alpha_{1}, \alpha_{2}, \beta_{1}, \beta_{2}$ to the twocompartment rate constants $\mathrm{k}_{21}, \mathrm{k}_{12}, \mathrm{k}_{01}$ (Table 3 ). The mean squared relative deviation between measured and fitted C-peptide concentrations was about $10 \%$ (range 5 to $18 \%$ ), and the precision of the individual estimates of the rate constants was about 10 to $20 \%$. Table 3 also shows the population-based kinetic parameters calculated according to methods de- scribed previously [17] and incorporated in the ISEC method $[18,19]$. The mean population-based parameters and the mean individual counterparts based on analysis of the C-peptide decay curve after intravenous bolus injection do not deviate significantly. The SEM of the rate constants from the intravenous bolus test reported in Table 3 correspond to standard deviations $(\mathrm{SD}=\mathrm{SEM} \cdot \sqrt{8})$ of 30 to $50 \%$, indicating a substantial variation between subjects compared to the precision of the individual estimates. In contrast, there was a much smaller variation between the individual population-based parameters, and the rate constants for the Type II diabetics were significantly higher than those of the controls athough the differences were relatively small. The rate constants from the intravenous bolus test and the derived parameters $\left(\mathrm{V}_{1}, \mathrm{~V}_{2}, \mathrm{Cl}\right)$ were not significantly different between the diabetic patients and the control subjects.

Intravenous glucose tolerance test. As expected, the fasting and stimulated glucose concentrations were higher in the patients than in the control subjects, 


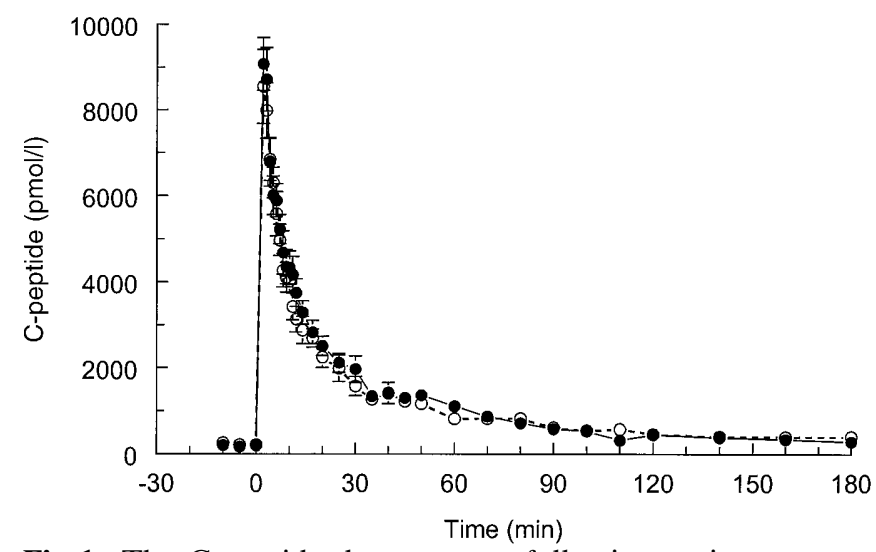

Fig. 1. The C-peptide decay curves following an intravenous bolus of $50 \mathrm{nmol}$ biosynthetic C-peptide. The mean curve for the non-diabetic control subjects (-O) and the mean curve for the Type II diabetic patients $\left(\mathrm{O}_{-}-\mathrm{O}\right)$

whereas the fasting plasma insulin and C-peptide concentrations were comparable between the two groups (Fig. 2). Patients with diabetes lacked firstphase insulin and C-peptide responses to glucose and showed only a small, blunted second-phase response to glucose plus tolbutamide. In contrast, the control subjects responded well to the glucose injection with a distinct first-phase insulin response followed by a large second-phase response. As expected, C-peptide plasma concentrations were higher than those of insulin and also showed biphasic dynamics.

Insulin secretion rates. The mean insulin secretion rates obtained with the deconvolution methods are shown in Figure 3. The reference method using individually estimated kinetic parameters and the ISEC method using population parameters gave similar results for both groups. The mean squared relative deviation between measured and fitted $\mathrm{C}$-peptide concentrations was typically 5 to $10 \%$. Because the $95 \%$-confidence limits for the mean difference include zero, there were no significant differences between the secretion rates obtained with the two methods. Control subjects showed a large first-phase secretion response lasting about $5 \mathrm{~min}$. Between 5 and $20 \mathrm{~min}$ the secretion rate began to fluctuate. The sec-
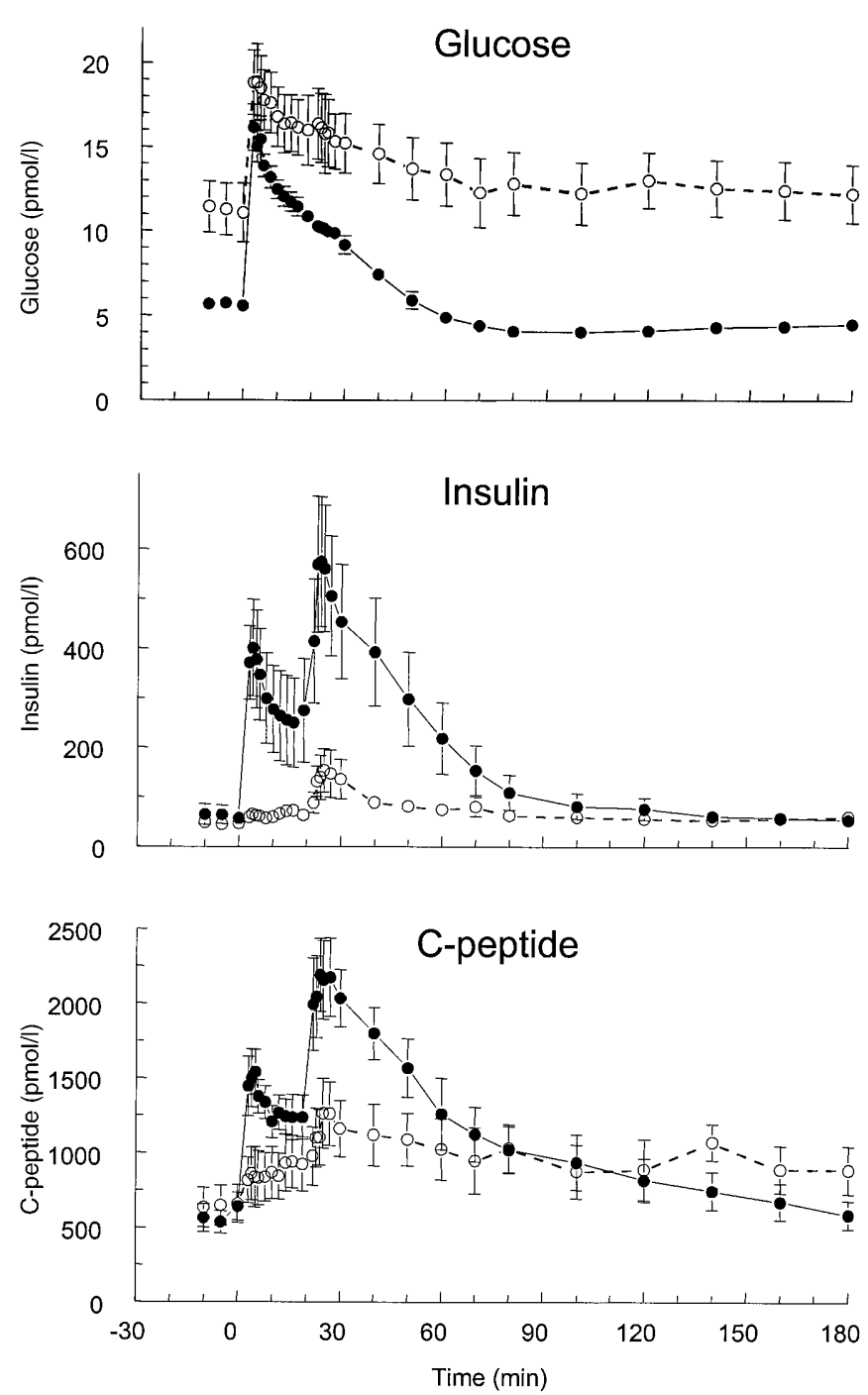

Fig. 2. Plasma glucose, insulin and C-peptide concentrations during the IVGTT. The means for the control subjects (-O). The means of the Type II diabetic patients $\left(\mathrm{O}_{-}-\mathrm{O}\right)$

ond-phase secretion response peaked after $20 \mathrm{~min}$ when tolbutamide was given and decreased subsequently approaching the fasting rate after about $60 \mathrm{~min}$. For the Type II diabetic patients, both methods were able to identify a small first-phase response where the concentration profiles had failed to do so. The second-phase secretion with a peak value similar

Table 3. C-peptide kinetic parameters estimated after intravenous bolus injection of C-peptide and the population-based values used by the ISEC program (means with SEM)

\begin{tabular}{lcccc}
\hline & \multicolumn{2}{c}{ Control subjects $(n=8)$} & & Type II diabetic patients $(n=8)$ \\
\hline Parameter & i.v. bolus exp. & ISEC & i.v. bolus exp. & ISEC \\
$\mathrm{k}_{21}\left(\mathrm{~min}^{-1}\right)$ & $0.084 \pm 0.017$ & $0.0556 \pm 0.0005$ & $0.081 \pm 0.013$ & $0.0632 \pm 0.0005$ \\
$\mathrm{k}_{12}\left(\mathrm{~min}^{-1}\right)$ & $0.076 \pm 0.012$ & $0.0480 \pm 0.0002$ & $0.055 \pm 0.008$ & $0.0488 \pm 0.0002$ \\
$\mathrm{k}_{01}\left(\mathrm{~min}^{-1}\right)$ & $0.066 \pm 0.006$ & $0.0553 \pm 0.0006$ & $0.065 \pm 0.007$ & $0.0607 \pm 0.0005$ \\
$\mathrm{~V}_{1}(\mathrm{l})$ & $4.51 \pm 0.51$ & $4.51 \pm 0.17$ & $4.68 \pm 0.45$ & $4.35 \pm 0.07$ \\
$\mathrm{~V}_{2}(\mathrm{l})$ & $4.88 \pm 0.78$ & $5.21 \pm 0.15$ & $7.60 \pm 1.53$ & $5.64 \pm 0.16$ \\
$\mathrm{Cl}\left(\mathrm{ml} \cdot \mathrm{kg}^{-1} \cdot \mathrm{min}^{-1}\right)$ & $3.08 \pm 0.13$ & $2.78 \pm 0.09$ & $3.39 \pm 0.41$ & $3.04 \pm 0.11$ \\
\hline
\end{tabular}



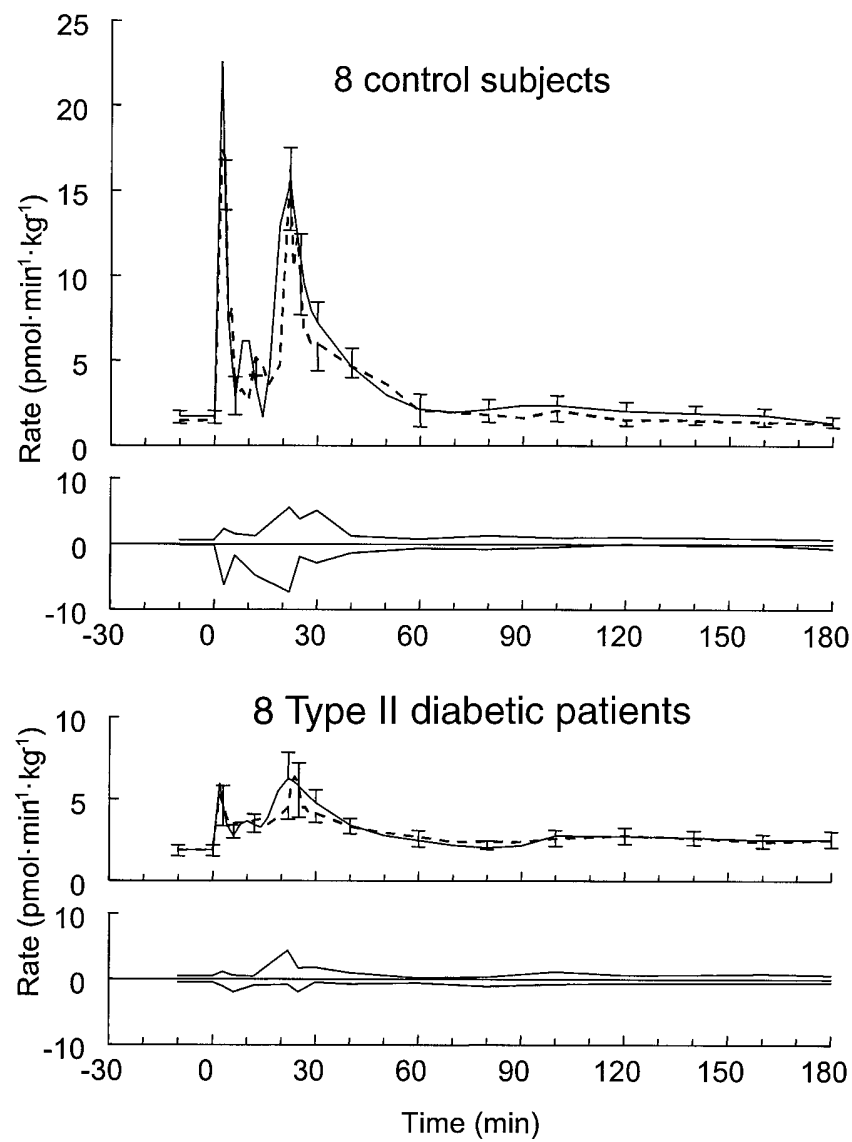

Fig. 3. Mean estimates and $95 \%$-confidence limits for the difference between secretion rates obtained with the deconvolution reference method based on individual C-peptide parameters (-) and the deconvolution method based on population parameters (- - ) for the control subjects in the two upper panels and for the Type II diabetic patients in the two lower panels

to the first phase peak and a prolonged duration as in the control subjects was also identified. The secondphase peak tended to be narrower with the ISEC than with the reference method.

The parameters of the combined models share only the insulin elimination rate constant $\mathrm{k}_{\mathrm{I}}$ (Table 4). $\mathrm{k}_{\mathrm{I}}$ is about twice as large with the two-compartment than with the one-compartment model. There was, however, a large variation between subjects and the accuracy of the individual parameter estimates was low and varied greatly from subject to subject with coefficients of variation around $50 \%$. The mean squared relative deviation between measured and fitted insulin and C-peptide concentrations was about $10 \%$ for the combined models. The C-peptide kinetic parameters of the two-compartment combined model can be compared with corresponding values in Table 3. The $\mathrm{k}_{01}$ and $\mathrm{k}_{21}$ in Table 4 are about twice as large as in Table 3 , while $\mathrm{k}_{12}$ is similar. The corresponding parameters from the Type II patients and the control subjects were not significantly different.

For the mean insulin secretion rates obtained with the combined one-compartment model and the deconvolution reference method, we found the profiles to be similar (Fig.4). However, the peak rate of the control subjects seems to be somewhat overestimated using the combined model and the second-phase response tends to decrease more rapidly using the combined model than with the reference method. A similar pattern of differences is seen with the Type II patients. The $95 \%$-confidence limits confirm that there are no statistically significant differences between the rates obtained with the two methods. The twocompartment combined model failed to provide reliable estimates of insulin secretion in three of the control subjects and in two of the diabetic subjects. The estimation was considered as a failure when one or more of the parameter estimates was negative. The mean secretion profiles of the five control subjects and the six Type II diabetics compared to the mean secretion profiles obtained with the reference method is shown in Figure 5. There is good agreement with respect to the basal rate and the first-phase secretion. The two-compartment combined model tends to overestimate the second-phase response considerably, but the difference did not reach statistical significance according to the $95 \%$-confidence limits.

The mean basal rate and the secretion responses for the first phase (0-10 min) and second phase $(10-180 \mathrm{~min})$ as well as the total secretion (0-180 min) are shown in Table 5. By paired tests the only significant difference between the reference method and each of the three other methods was

Table 4. Kinetic parameters estimated for the one- and two-compartment combined models of insulin and C-peptide kinetics during IVGTT (means with SEM)

\begin{tabular}{|c|c|c|c|c|}
\hline \multirow[b]{2}{*}{ Parameter } & \multicolumn{2}{|l|}{ Control subjects } & \multicolumn{2}{|l|}{ Type II diabetic patients } \\
\hline & One-compartment $n=8$ & Two-compartment $n=5$ & One-compartment $n=8$ & Two-compartment $n=6$ \\
\hline $\mathrm{f}=\mathrm{F} \cdot \mathrm{V}_{\mathrm{I}} / \mathrm{V}_{\mathrm{C}}$ & $0.41 \pm 0.05$ & & $0.29 \pm 0.07$ & \\
\hline $\mathrm{k}_{\mathrm{C}}\left(\min ^{-1}\right)$ & $0.024 \pm 0.007$ & & $0.037 \pm 0.012$ & \\
\hline $\mathrm{F} \cdot \mathrm{V}_{\mathrm{I}} / \mathrm{V}_{1}$ & & $4.05 \pm 1.08$ & & $5.75 \pm 0.87$ \\
\hline $\mathrm{k}_{21}\left(\min ^{-1}\right)$ & & $0.120 \pm 0.077$ & & $0.177 \pm 0.064$ \\
\hline $\mathrm{k}_{12}\left(\min ^{-1}\right)$ & & $0.030 \pm 0.008$ & & $0.067 \pm 0.018$ \\
\hline
\end{tabular}



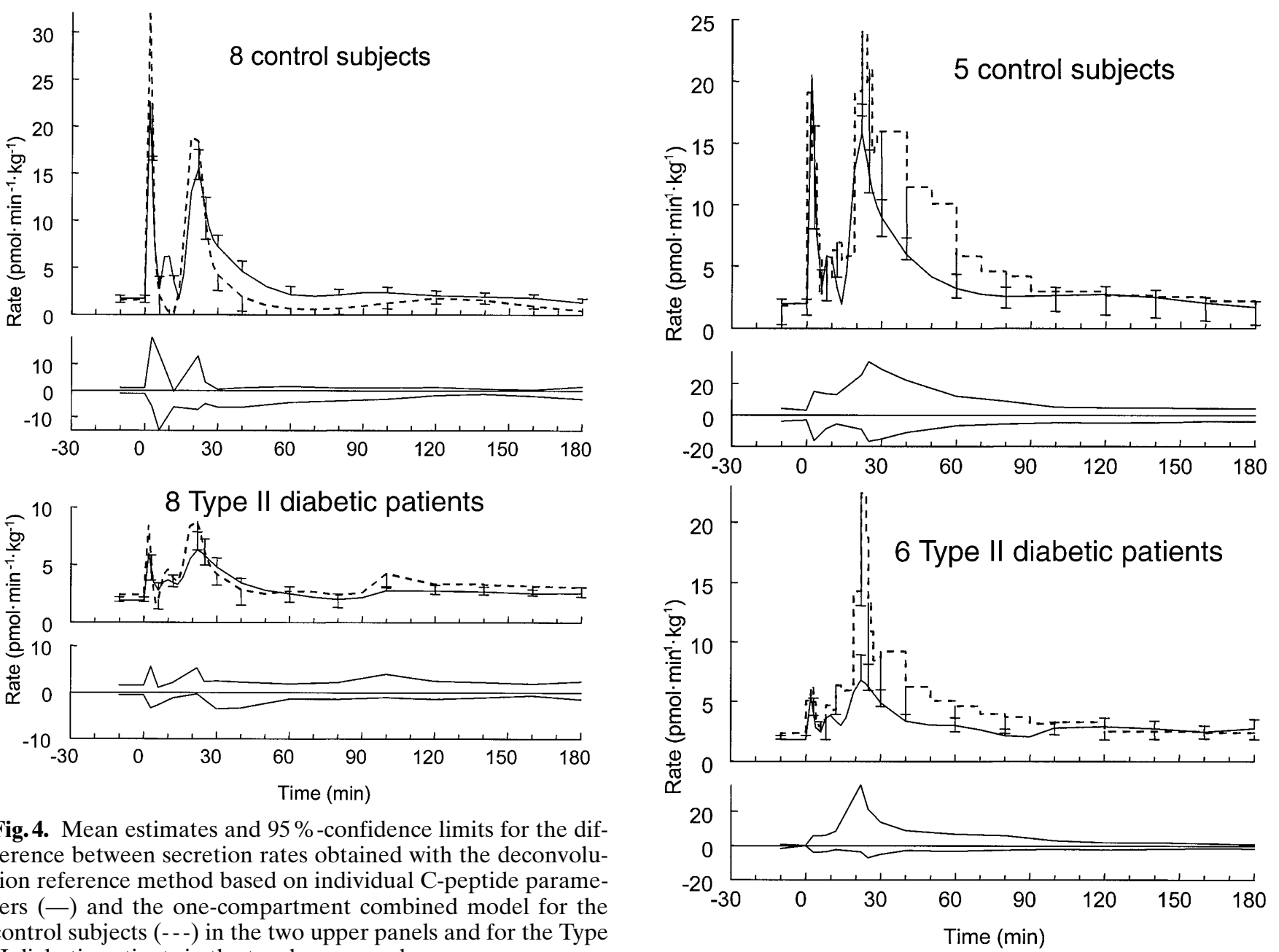

Fig. 4. Mean estimates and $95 \%$-confidence limits for the difference between secretion rates obtained with the deconvolution reference method based on individual C-peptide parameters (-) and the one-compartment combined model for the control subjects (--) in the two upper panels and for the Type II diabetic patients in the two lower panels

seen with the first-phase response obtained by the ISEC method in the control group. The difference was, however, relatively small (about $15 \%$ ). Table 5 shows also the results of the statistical comparisons for each method and secretion response between the control subjects and the Type II patients. Both deconvolution methods and the one-compartment combined model show significant differences in the firstphase response between the two groups. The magnitude of the standard errors indicates that the variation between subjects is similar for the deconvolution methods and higher with the combined models, in particular for the two-compartment model and the second-phase and total secretion responses.

Table 6 shows the correlation coefficients between the secretion responses with the reference method and the three other methods. All secretion responses were highly correlated for the two deconvolution methods while only the first-phase response with the combined models showed a significant correlation to the reference method.

Fig. 5. Mean estimates and $95 \%$-confidence limits for the difference between secretion rates obtained with the deconvolution reference method based on individual C-peptide parameters (-) and the two-compartment combined model for the control subjects (--) in the two upper panels and for the Type II diabetic patients in the two lower panels. Because the twocompartment combined model was not able to calculate secretion rates for all subjects, only results from five of the control subjects and six of the Type II diabetic subjects are shown

\section{Discussion}

In our study, the two deconvolution methods $[15,16$, $18,19]$ gave similar secretion results (Fig. 3, Tables 5 and 6) as expected from the similarity of the individually estimated and population-based kinetic parameters for C-peptide. The relatively small deviations (5-10\%) between measured and fitted C-peptide concentrations indicate that the two-compartment model was adequate. In the Type II diabetic patients, the methods were able to identify a small first-phase insulin response even when the concentration profiles of C-peptide did not. The second phase was also identified, although the second-phase peak tended to be narrower with the ISEC than the reference method. This could be explained by differences be- 
Table 5. Insulin secretion responses during IVGTT with tolbutamide obtained with the four methods

\begin{tabular}{|c|c|c|c|c|c|c|c|c|c|}
\hline \multirow[b]{2}{*}{ Method } & \multirow[b]{2}{*}{ Subjects } & \multicolumn{2}{|c|}{$\begin{array}{l}\text { Basal secretion rate } \\
\left(\mathrm{pmol} \cdot \mathrm{min}^{-1} \cdot \mathrm{kg}^{-1}\right)\end{array}$} & \multicolumn{2}{|c|}{$\begin{array}{l}\text { 1st phase secretion } \\
0-10 \mathrm{~min}(\mathrm{pmol} / \mathrm{kg})\end{array}$} & \multicolumn{2}{|c|}{$\begin{array}{l}\text { 2nd phase secretion } \\
10-180 \mathrm{~min}(\mathrm{pmol} / \mathrm{kg})\end{array}$} & \multicolumn{2}{|c|}{$\begin{array}{l}\text { Total secretion } \\
0-180 \mathrm{~min}(\mathrm{pmol} / \mathrm{kg})\end{array}$} \\
\hline & & $n$ & Means \pm SEM & $n$ & Means \pm SEM & $n$ & Means \pm SEM & $n$ & Means \pm SEM \\
\hline $\begin{array}{l}\text { individual } \\
\text { parameters }\end{array}$ & $\begin{array}{l}\text { Type II diabetic } \\
\text { patients }\end{array}$ & 8 & $1.9 \pm 0.3$ & 8 & $37 \pm 7^{c}$ & 7 & $483 \pm 68$ & 7 & $519 \pm 72$ \\
\hline ISEC & Control subjects & 8 & $1.5 \pm 0.2$ & 8 & $73 \pm 8^{a}$ & 8 & $459 \pm 62$ & 8 & $532 \pm 57$ \\
\hline Combined & Control subjects & 8 & $1.6 \pm 0.8$ & 8 & $91 \pm 15$ & 8 & $372 \pm 105$ & 8 & $463 \pm 113$ \\
\hline $\begin{array}{l}\text { model, one- } \\
\text { compartment }\end{array}$ & $\begin{array}{l}\text { Type II diabetic } \\
\text { patients }\end{array}$ & 8 & $2.4 \pm 0.6$ & 8 & $41 \pm 9^{b}$ & 7 & $600 \pm 152$ & 7 & $642 \pm 158$ \\
\hline Combined & Control subjects & 5 & $1.9 \pm 1.0$ & 5 & $94 \pm 22$ & 5 & $1021 \pm 536$ & 5 & $1115 \pm 555$ \\
\hline $\begin{array}{l}\text { model, two- } \\
\text { compartment }\end{array}$ & $\begin{array}{l}\text { Type II diabetic } \\
\text { patients }\end{array}$ & 6 & $2.4 \pm 1.0$ & 6 & $44 \pm 14$ & 5 & $562 \pm 202$ & 5 & $593 \pm 204$ \\
\hline
\end{tabular}

${ }^{a} p<0.05$ Significant difference relative to reference deconvolution method (individual parameters)

${ }^{\mathrm{b}} p<0.05,{ }^{\mathrm{c}} p<0.001$ Significant difference relative to control subjects

Table 6. Correlation coefficients between secretion responses obtained with the deconvolution reference method and the other methods

\begin{tabular}{llllr}
\hline Method & Basal rate & 1st phase 0-10 min & 2nd phase 10-180 min & Total 0-180 min \\
\hline ISEC population parameters & $0.83^{\mathrm{a}}(16)$ & $0.92^{\mathrm{a}}(16)$ & $0.81^{\mathrm{a}}(15)$ & $0.80^{\mathrm{a}}(15)$ \\
Combined one-compartment & $0.40(16)$ & $0.78^{\mathrm{a}}(16)$ & $0.12(15)$ & $0.08(15)$ \\
Combined two-compartment & $0.11(11)$ & $0.80^{\mathrm{a}}(11)$ & $-0.05(10)$ & $-0.05(10)$ \\
\hline
\end{tabular}

${ }^{\mathrm{a}} p<0.001$ (product moment correlation)

Number in bracket is number of subjects

tween the two deconvolution methods, i.e. the smoothing factor in the ISEC programme and the spline representation of the secretion rate with the reference method based on individual C-peptide kinetics. The variation between the subjects is, however, always much larger with the experimentally determined parameters than for the population-based ones. This is presumably because the populationbased method underestimates the variation between subjects as well as the intra-subject variation in the parameter estimates.

The relative deviations between the measured insulin and C-peptide concentration and those fitted according to the one-compartment combined model were also relatively small (about $10 \%$ ) indicating that the model gives an acceptable approximation $[23,24]$. Our data show that during rapid changes in secretion, the rates of pre-hepatic insulin secretion obtained with the one-compartment combined model were not significantly different from those obtained with the reference method (Fig. 4). The peak values seem to be somewhat overestimated and the secondphase response with the combined model tends to decrease more rapidly in the control subjects. The onecompartment combined model yields similar esti- mates for the first-phase secretion, while basal and second-phase secretion were more variable though not significantly different from the results obtained with the reference method (Tables 5 and 6). Only the first-phase secretion showed a significant correlation between the two methods. The combined model, contrary to expectations, seems to be more accurate in estimating the rapid first-phase response than the slower second phase and the basal insulin secretion. In previous validation studies, the combined model was able to estimate relatively slowly varying known rates of human insulin and C-peptide administered to dogs [23] as well as to control subjects and Type II diabetic patients [31]. Recently, investigators [14] compared the one-compartment combined model and the deconvolution technique in pancreas- and kidney-transplanted Type I diabetic patients as well as in normal control subjects and kidney-transplanted patients during an OGTT and a glucagon test. The combined model seemed to overestimate the rates in the early poststimulatory phase of insulin secretion and to underestimate in the later phase when compared to the deconvolution reference method.

The combined model with two-compartment kinetics for C-peptide which introduces more unknown 
parameters to be estimated could require more precise data showing pronounced dynamics $[25,26]$ but it should in theory give a more accurate estimation of the insulin secretion than the one-compartment model $[23,24]$. In this study the modified two-compartment combined model $[25,26]$ was only able to estimate insulin secretion profiles in five out of eight control subjects and in six out of eight patients with Type II diabetes. The two-compartment model gave similar estimates for basal and first-phase secretion as the other methods (Table 5). The second-phase secretion tended, however, to be overestimated probably because of the addition of a second compartment to the C-peptide kinetic model rendering parameter identification more difficult or impossible depending on the precision of the measurements and the biological variation. It is possible that some modification, e.g. reweighting of the data, might improve the performance of the two-compartment model.

A similar problem concerning estimates of the kinetic parameters of the two-compartment model for C-peptide has been observed in a study [21] which evaluated the accuracy of the minimal model of glucose-dependent C-peptide secretion for the IVGTT in non-diabetic, healthy subjects. As rather large differences were observed between the estimated parameters and the population-based values the authors suggested that the population-based values should be used. A comparison of the estimates of $\mathrm{k}_{21}, \mathrm{k}_{12}$, and $\mathrm{k}_{01}$ in Table 4 with the corresponding population-based values or the $i$. v. bolus test parameters in Table 3 also shows relatively large deviations, indicating the difficulties involved in identification of the parameters of the two-compartment combined model.

Estimates of $\mathrm{k}_{\mathrm{I}}$ are about twice as large with the two-compartment model relative to the one-compartment model and in the Type II patients compared to the control subjects (Table 4). Of note, differences between the estimated secretion rates are much smaller than the differences between the estimates of the underlying kinetic parameters. This phenomenon has also been observed in a simulation study of the ability of the one-compartment combined model to estimate secretion rates when realistic random errors were added to the concentrations of insulin and C-peptide [24]. In other words, the secretion rates measured by the combined model are more accurate than the estimates of the underlying kinetic parameters. Overall, the combined models perform better in estimating the rapid first-phase secretion than the second phase. This could, however, be an advantage because it is the first-phase response that is of vital interest.

The rather small and insignificant correlation coefficients (Table 6) between the reference method and the combined model methods for the basal secretion, the second-phase and the total secretion responses, can be explained by the relatively large variation in these responses from the combined models (Table 5).

In summary, our data show that the deconvolution methods based on individual or population-based Cpeptide kinetic parameters and the combined model all give similar estimates of the basal and first-phase insulin secretion during an IVGTT. The two-compartment combined model could not estimate secretion rates in 5 of the 16 subjects and tended to overestimate the second-phase secretion. Taking the deconvolution method with independent assessment of Cpeptide kinetics as the reference method, it can be concluded that the population-parameter-based deconvolution method as well the one-compartment combined model are also accurate in assessing rapid changes in insulin secretion, i.e. the first-phase response of IVGTT in control subjects and Type II diabetic patients.

We recommend applying the ISEC method to subjects that can be classified as normal, obese or Type II diabetic and who can be expected to show normal Cpeptide kinetics. In subjects where deviating kinetics of C-peptide cannot be excluded (e.g. pancreas- and kidney-transplanted patients), the one-compartment combined model or the deconvolution method with individual assessment of C-peptide kinetics is to be recommended.

Acknowledgements. We thank Dr. R Hovorka for kindly providing us the ISEC programme and B. Jensen for her expert secretarial assistance. We also thank Dr. R. Watanabe for giving us access to the programme for analysis of the two-compartment combined model. This work was supported by the Academy of Technical Sciences and Novo Nordisk, the Novo Nordisk Foundation, the Danish Diabetes Foundation, Poul and Erna Sehested Hansens Fond and the Research Foundation for Copenhagen, Greenland and Faroe Islands.

\section{References}

1. DeFronzo RA (1992) Pathogenesis of Type II diabetes (non-insulin dependent) diabetes mellitus: a balanced overview. Diabetologia 35: 389-397

2. DeFronzo RA Lilly Lecture 1987 (1988) The triumvirate: $\beta$-cell, muscle, liver: a collision responsible for NIDDM. Diabetes 37: 667-687

3. Byrne MM, Sturis J, Sobel RJ, Polonsky KS (1996) Elevated plasma glucose $2 \mathrm{~h}$ post challenge predicts defects in $\beta$ cell function. Am J Physiol 96: E572-E579

4. Kahn SE, Prigeon RL, McCulloch DK et al. (1993) Quantification of the relationship between insulin sensitivity and beta-cell function in human subjects. Evidence for a hyperbolic function. Diabetes 42: 1663-1672

5. Polonsky KS (1995) The B-cell in diabetes: From molecular genetics to clinical research. Diabetes 44: 705-717

6. Polonsky KS, Rubenstein AH (1984) C-peptide as a measure of the secretion and hepatic extraction of insulin: pitfalls and limitations. Diabetes 33: 486-494

7. Polonsky KS, Jaspan JB, Pugh W et al. (1983) Metabolism of C-peptide in the dog: in vivo demonstration of the absence of hepatic extraction. J Clin Invest 72: 1114-1123 
8. Eaton RP, Allen RC, Shade DS (1983) Hepatic removal of insulin in normal man: dose response to endogenous insulin secretion. J Clin Endocrinol Metab 56: 1294-1300

9. Rubenstein AH, Clark JL, Melani F, Steiner DF (1969) Secretion of proinsulin C-peptide by pancreatic beta-cells and its circulation in blood. Nature 224: 697-699

10. Shapiro ET, Tillil H, Rubenstein AH, Polonsky KS (1988) Peripheral insulin parallels changes in insulin secretion more closely than C-peptide after bolus intravenous glucose administration. J Clin Endocrinol Metab 67: 1094-1099

11. Faber OK, Madsbad S, Kehlet H, Binder C (1979) Pancreatic $\beta$-cell secretion during oral and intravenous glucose administration. Acta Med Scand Suppl 624: 61-64

12. Gibby OM, Hales CN (1975) Oral glucose decreases hepatic extraction of insulin. BMJ 286: 921-923

13. Madsbad S, Kehlet H, Hilsted J, Tronier B (1983) Discrepancy between plasma C-peptide and insulin response to oral and intravenous glucose. Diabetes 32: 436-438

14. Christiansen E, Kjems LL, Vølund A, Tibell A, Binder C, Madsbad S (1998) Insulin secretion estimated by two mathematical methods in pancreas-kidney transplant recipients. Am J Physiol 274: E716-E725

15. Eaton RP, Allen RC, Shade DS, Erickson KM, Standefer J (1980) Pre-hepatic insulin production in man: kinetic analysis using peripheral connecting peptide behaviour. J Clin Endocrinol Metab 51: 520-528

16. Polonsky KS, Licinio-Paixao J, Given BD et al. (1986) Use of biosynthetic human C-peptide in the measurement of insulin secretion rates in normal volunteers and type 1 diabetic patients. J Clin Invest 77: 98-105

17. Van Cauter E, Mestrez F, Sturis J, Polonsky KS (1992) Estimation of insulin secretion rates from C-peptide levels. Comparison of individual and standard kinetic parameters for C-peptide clearance. Diabetes 41: 368-377

18. Hovorka R, Soons PA, Young MA (1996) ISEC: a program to calculate insulin secretion. Comput Methods Programs Biomed 50: 253-264

19. Hovorka R, Koukou E, Southernden D, Powrie JK, Young MA (1998) Measuring prehepatic insulin secretion using a population model of C-peptide kinetics: accuracy and required sampling schedule. Diabetologia 41: 548-554

20. Cobelli C, Pacini G (1988) Insulin secretion and hepatic extraction in humans by minimal modelling of C-peptide and insulin kinetics. Diabetes 37: 223-231

21. Toffolo G, De Grandi F, Cobelli C (1995) Estimation of $\beta$ cell sensitivity from intravenous glucose tolerance test Cpeptide data. Diabetes 44: 845-854

22. Toffolo G, Breda E, Cavaghan MK, Ehrman DA, Polonsky KS, Cobelli C (2001) Quantification indexes of beta-cell function during graded up and down glucose infusion from C-peptide minimal models. Am J Physiol Endocrinol Metab 280: E2-E10

23. Vølund A, Polonsky KS, Bergman RN (1987) Calculated pattern of intraportal insulin appearance without independent assessment of C-peptide kinetics. Diabetes 36: 1195-1202

24. Vølund A (1991) Estimation of equimolar cosecretion rates of insulin and C-peptide from concentration profiles. Assessment of precision by stochastic simulations. In: Vichnevetsky R, Miller JJH (eds) Proceeding of the 13th IMACS World Congress on Computation and applied mathematics, Criterion, Dublin vol3, pp 1482-1483

25. Watanabe RM, Steil GM, Bergman RN (1998) Critical evaluation of the combined model approach for estimation of pre-hepatic insulin secretion. Am J Physiol 274: E172-E183

26. Watanabe RM, Bergman RN (2000) Accurate assessment of endogenous insulin secretion does not require separate assessment of C-peptide kinetics. Diabetes 49: 373-382

27. Walton C, Godsland IF, Proudler AJ, Felton C, Wynn V (1992) Evaluation of four mathematical models of glucose and insulin dynamics with analysis of effects of age and obesity. Am J Physiol 92: E755-E762

28. Polonsky KS, Given BD, Pugh W et al. (1986) Calculation of the systemic delivery rate of insulin in normal man. J Clin Endocrinol Metab 63: 113-118

29. Sturis J, Van Cauter E, Blackman JD, Polonsky KS (1991) Entrainment of pulsatile insulin secretion by oscillatory glucose infusion. J Clin Invest 87: 439-445

30. Byrne MM, Sturis J, Polonsky KS (1995) Insulin secretion and clearance during low-graded glucose infusion. Am J Physiol 268: E21-E27

31. Kjems LL, Christiansen E, Vølund A, Bergman RN, Madsbad S (2000) Validation of methods for measurement of insulin secretion in vivo. Diabetes 49: 580-588

32. Andersen L, Dinesen B, Jorgensen PN, Poulsen F, Roder ME (1993) Enzyme immunoassay for intact human insulin in serum or plasma. Clin Chem 39: 578-582

33. Heding LG (1975) Radio immunological determination of human C-peptide in serum. Diabetologia 11: 541-548

34. Faber OK, Markussen J, Naithani VK, Binder C (1976) Production of antisera to synthetic benzylcarbonyl C-peptide of human proinsulin. Hoppe-seyler Z. Physiol Chem 357: 751-757

35. Faber OK, Hagen C, Binder C et al. (1978) Kinetics of human connecting peptide in normal and diabetic subjects. J Clin Invest 62: 197-203 